\title{
Tetrasphaera remsis sp. nov., isolated from the Regenerative Enclosed Life Support Module Simulator (REMS) air system
}

Correspondence

Kasthuri Venkateswaran kjvenkat@jpl.nasa.gov
The genus Tetrasphaera currently comprises seven species, Tetrasphaera australiensis, T. elongata, T. duodecadis, T. japonica, T. jenkinsii, T. vanveenii and $T$. veronensis

Abbreviations: DAP, diaminopimelic acid; EM, electron microscope; ISS, International Space Station; REMS, Regenerative Enclosed Life Support Module Simulator.

tPresent address: Center for Environmental Biotechnology, Lawrence Berkeley National Laboratory, 1 Cyclotron Road, Berkeley, CA 94720, USA.

The GenBank/EMBL/DDBJ accession numbers for the 16S rRNA gene sequences of strains 3-M5-R-4 ${ }^{\top}$ and 3-M5-R-7 are DQ447774 and EF028236, respectively.

A figure showing TLC analysis of whole-cell hydrolysates is available as supplementary material with the online version of this paper.
(Hanada et al., 2002; Ishikawa \& Yokota, 2006; Maszenan et al., 2000; McKenzie et al., 2006). Most of these species were isolated from wastewater sludge. However, two phenotypically and genotypically distinct strains of bacteria related to the genus Tetrasphaera were isolated recently from air samples collected from a class $100 \mathrm{~K}$ clean room.

The Regenerative Enclosed Life Support Module Simulator (REMS) system was constructed to simulate conditions aboard the International Space Station (ISS) and to create an environment for testing reclamation technologies for future ISS implementation. Crew activity was simulated using volunteers who exercised, performed prescribed hygienic activities (e.g. face washing and tooth brushing with carefully measured quantities of water) and prepared 
pre-packaged meals (Carter et al., 2005). The REMS facility as a whole was maintained as a class $100 \mathrm{~K}$ clean room (cumulative distribution of particles $>0.5 \mu \mathrm{m}$ per one cubic foot of air) during its operational phase through stringent maintenance protocols that included controlled air circulation and filtration. The REMS system provided an extreme, unique, encapsulated environment for humans and their associated microbes. The microbial diversity of the REMS atmosphere was characterized recently using state-of-the-art molecular methods to establish criteria necessary for providing an environment that promotes the health, safety and productivity of the ISS crew-members (Moissl et al., 2007). While cataloguing cultivable microbes, two novel strains, 3-M5-R-4 ${ }^{\mathrm{T}}$ and 3-M5-R-7, with unique morphology and taxonomic characteristics were isolated and characterized.

During the characterization of organisms isolated from REMS air, strains 3-M5-R-4 ${ }^{\mathrm{T}}$ and 3-M5-R-7 were recovered from low nutrient media under mesophilic conditions, appearing as beige-coloured colonies. All further cultivation was carried out on R2A medium (Difco) at $25{ }^{\circ} \mathrm{C}$ for 7 days. Isolates were capable of growth at 15 $45^{\circ} \mathrm{C}$, but did not grow under psychrophilic conditions. Results of physiological characterization using API 20E and API 20NE kits (bioMérieux) are given in the species description. Oxidation of various carbon sources was tested by using Biolog GP2 MicroPlates. The plates were used according to the manufacturer's instructions except that R2A liquid medium was used instead of Biolog Universal Growth medium. The inoculated plates were incubated for $72 \mathrm{~h}$ and the results were read with a MicroPlate Reader using Microlog 4.2 computer software. Table 1 shows the differential characteristics of the newly described strains and T. japonica DSM $13192^{\mathrm{T}}$, a closely related strain (16S rRNA gene sequence similarity of $\sim 98 \%$ with the isolates). The newly described strains were oxidase-negative and able to liquefy gelatin and so could be readily distinguished from their nearest neighbour. Several sugars (e.g. sucrose and trehalose) and organic compounds were utilized by the novel strains, but not by T. japonica. Also, T. japonica grew between 15 and $37{ }^{\circ} \mathrm{C}$, but failed to grow at $45{ }^{\circ} \mathrm{C}$.

Morphology of cells grown for 3 days at $25{ }^{\circ} \mathrm{C}$ on R2A or in liquid medium was observed under an Olympus light microscope at $\times 1000$ magnification. For cryo-electron tomography, cells grown for 3 days in liquid medium were plunge-frozen together with $10 \mathrm{~nm}$ gold fiducial markers across a glow-discharged, copper/rhodium electron microscope (EM) grid with R 2/2 carbon-on-film Quantifoil (Quantifoil Micro Tools). A $4 \mu \mathrm{l}$ drop of cell culture mixed with fiducial gold markers was applied to the EM grid at $100 \%$ humidity, automatically blotted and plunged into liquid ethane using a Vitrobot (FEI). The prepared grids were stored under liquid nitrogen. Images were collected using the FEI Polara, a $300 \mathrm{kV}$ field emission gun transmission EM equipped with an energy filter (slit width $20 \mathrm{eV}$ ) and a Gatan Ultrascan CCD camera. Single projections were collected from $-63^{\circ}$ to $+63^{\circ}$ in 1 degree increment steps using the predictive UCSF_Tomo software package (Zheng et al., 2004). The dataset was recorded at $12 \mu \mathrm{m}$ underfocus and a total electron dose of $160 \mathrm{e}^{-}$ $\AA^{-2}$. The tomogram was reconstructed by weighted backprojection using the IMOD software package (Mastronarde, 1997).

All cells showed a Gram-positive wall. As observed in $T$. japonica (Maszenan et al., 2000), the cell wall of the novel strains consisted of three visible layers: an inner electrondense layer, which was closely associated with the cytoplasmic membrane, an electron-lucent layer and, on the outside, another electron-dense layer (Fig. 1). As observed in T. vanveenii (McKenzie et al., 2006), there were two layers of capsular material in $3 \mathrm{M} 5-\mathrm{R}-4^{\mathrm{T}}$, an electronlucent layer that surrounded each cell and an electrondense layer that surrounded the entire cluster of cells (Fig. 1). A thin strand of material from this outer capsule continued into the centre of the septum separating the cells. In contrast to the type strains of T. jenkinsii, $T$. vanveenii and $T$. veronensis, the novel isolates always grew as cocci in diploid, tetrad and cluster arrangements on all the media examined and filamentous growth was not observed.

The $\mathrm{G}+\mathrm{C}$ content of genomic DNA was determined as described previously (Saha et al., 2005). The $\mathrm{G}+\mathrm{C}$ content of strain $3 \mathrm{MSR}-4^{\mathrm{T}}$ was $69.2 \mathrm{~mol} \%\left(T_{\mathrm{m}} 81.5{ }^{\circ} \mathrm{C}\right)$. Both strains examined in this study produced polyphosphate (Murray et al., 1994), as observed in other Tetrasphaera species. The diastereoisomer of diaminopimelic acid (DAP) in cell-wall hydrolysates of strains $3 \mathrm{M} 5-\mathrm{R}-4^{\mathrm{T}}$ and 3M5-R-7 was determined (Staneck \& Roberts, 1974). Briefly, $20 \mathrm{mg}$ freeze-dried cells was hydrolysed with $200 \mu \mathrm{l} 6 \mathrm{M} \mathrm{HCl}$ in a $100{ }^{\circ} \mathrm{C}$ water-bath for $18 \mathrm{~h}$. Following hydrolysis, the cell mixture was filtered through an activated charcoal column and dried completely in a concentrator (Turbo-Vap; Zymarck) and then dissolved in $200 \mu \mathrm{l}$ sterile double-distilled water. A total of $5 \mu \mathrm{l}$ hydrolysate was applied on a TLC plate (Merck 5577) along with standard DAP and developed in a TLC tank containing a methanol/water/10 M HCl/pyridine $(80: 17.5: 2.5: 10$, by vol.) mixture for $3 \mathrm{~h}$. The TLC plate was dried under a fume hood and sprayed with a $0.2 \%$ ninhydrin solution. Plates were finally heated to 100 $105{ }^{\circ} \mathrm{C}$. After about $5 \mathrm{~min}$, hydrolysate DAP was visualized as a grey-green colour when compared against the standard DAP. Analysis of the cell-wall hydrolysates of strains $3 \mathrm{M} 5-\mathrm{R}-4^{\mathrm{T}}$ and $3 \mathrm{M} 5-\mathrm{R}-7$ revealed the presence of meso-DAP as its diagnostic cell-wall dibasic amino acid, which was also present in the Tetrasphaera type strains analysed in this study (see Supplementary Fig. S1 available in IJSEM Online).

Phylogenetic analysis was performed using the ARB software package (Ludwig et al., 2004). Distances and clustering with the neighbour-joining and maximum-parsimony methods were determined by using bootstrap values based on 1000 replications. The 16S rRNA gene sequences of 
Table 1. Differential characteristics of strains $3 M 5-R-4^{\top}$ and 3M5-R-7 and T. japonica DSM $13192^{\top}$

Characteristics shown in bold can be used to distinguish the novel strains, 3M5-R-4 ${ }^{\mathrm{T}}$ and 3M5-R-7, from T. japonica DSM $13192^{\mathrm{T}}$. All three strains were cocci, occurring singly and in diploid, tetrad and cluster arrangements (cells $0.5-1.0 \mu \mathrm{m}$ diameter). They all grew at pH 6.0-8.0; optimum growth was observed at $\mathrm{pH} 7.0$ and $25^{\circ} \mathrm{C}$. All were positive for catalase and negative for nitrate reduction and production of urease, indole and $\mathrm{H}_{2} \mathrm{~S}$. All strains were positive for oxidation of D-galactose, maltose, D-ribose, turanose and L-malic acid and negative for oxidation of $\alpha$-cyclodextrin, glycogen, inulin, mannan, $\quad N$-acetyl-D-glucosamine, $\quad N$-acetyl- $\beta$-D-mannosamine, amygdalin, D-arabitol, D-gluconic acid, myo-inositol, $\alpha$-D-lactose, lactulose, mannitol, D-melibiose, methyl $\alpha$-D-galactoside, methyl $\beta$-Dglucoside, methyl $\alpha$-D-mannoside, D-psicose, D-raffinose, L-rhamnose, sedoheptulosan, stachyose, D-tagatose, $\alpha$-hydroxybutyric acid, $\beta$ hydroxybutyric acid, $p$-hydroxyphenylacetic acid, $\alpha$-ketoglutaric acid, $\alpha$-ketovaleric acid, lactamide, D-lactic acid methyl ester, L-lactic acid, D-malic acid, pyruvic acid methyl ester, succinic acid monomethyl ester, propionic acid, succinamic acid, succinic acid, $N$-acetyl-Lglutamic acid, L-alaninamide, L-alanine, L-alanyl glycine, L-asparagine, glycyl L-glutamic acid, L-pyroglutamic acid, L-serine, putrescine, 2,3butanediol, 2'-deoxyadenosine, inosine, thymidine, uridine, AMP, TMP, UMP, D-fructose 6-phosphate, $\alpha$-D-glucose 1-phosphate, Dglucose 6-phosphate and DL- $\alpha$-glycerol phosphate. ND, Not determined.

\begin{tabular}{|c|c|c|c|}
\hline Characteristic & $\begin{array}{c}\text { Strain } \\
\text { 3M5-R-4 }\end{array}$ & $\begin{array}{c}\text { Strain } \\
\text { 3M5-R-7 }\end{array}$ & $\begin{array}{c}\text { T. japonica } \\
\text { DSM } 13192^{\mathrm{T}}\end{array}$ \\
\hline $\begin{array}{l}\text { Growth temperature range } \\
\left({ }^{\circ} \mathrm{C}\right)\end{array}$ & $15-45$ & $15-45$ & $15-37$ \\
\hline Oxidase & - & - & + \\
\hline Gelatin hydrolysis & + & + & - \\
\hline \multicolumn{4}{|c|}{ Oxidation of substrates using Biolog GP2 } \\
\hline \multicolumn{4}{|l|}{ MicroPlates } \\
\hline$\beta$-Cyclodextrin & - & - & + \\
\hline Dextrin & + & + & - \\
\hline Tween 40 & - & + & - \\
\hline Tween 80 & + & - & - \\
\hline L-Arabinose & - & + & + \\
\hline Arbutin & + & - & - \\
\hline D-Cellobiose & + & + & - \\
\hline D-Fructose & + & + & - \\
\hline L-Fucose & - & - & + \\
\hline D-Galacturonic acid & - & + & - \\
\hline Gentiobiose & - & + & - \\
\hline$\alpha$-D-Glucose & + & + & - \\
\hline Maltotriose & + & + & - \\
\hline Mannose & - & + & - \\
\hline D-Melezitose & + & + & - \\
\hline Methyl $\beta$-D-galactoside & + & - & - \\
\hline 3-Methyl D-glucose & + & + & - \\
\hline Methyl $\alpha$-D-glucoside & + & - & - \\
\hline Palatinose & + & + & - \\
\hline Salicin & + & + & - \\
\hline D-Sorbitol & - & + & - \\
\hline Sucrose & + & + & - \\
\hline Trehalose & + & + & - \\
\hline
\end{tabular}

\begin{tabular}{|lccc|}
\hline Characteristic & Strain & Strain & T. japonica \\
& 3M5-R-4 & 3M5-R-7 DSM 13192 $^{\mathrm{T}}$ \\
\hline Xylitol & - & - & + \\
D-Xylose & + & + & - \\
Acetic acid & + & + & - \\
$\gamma$-Hydroxybutyric acid & - & + & - \\
Pyruvic acid & + & + & - \\
D-Alanine & - & + & - \\
L-Glutamic acid & - & + & - \\
Glycerol & + & + & - \\
Adenosine & + & + & - \\
Uridine & - & + & + \\
D-Fructose 6-phosphate & - & + & - \\
DNA G+C content (mol\%) & 69.2 & ND & 70 \\
& & & \\
\hline
\end{tabular}

strains 3-M5-R-4 ${ }^{\mathrm{T}}$ and 3-M5-R-7 were continuous stretches of $1250 \mathrm{bp}$ and were compared with those of known Tetrasphaera species (Blackall et al., 2000; Hanada et al., 2002; Maszenan et al., 2000). The parsimony-analysis-based phylogenetic tree is illustrated in Fig. 2. Sequences from strains $3 \mathrm{M} 5-\mathrm{R}-4^{\mathrm{T}}$ and $3 \mathrm{M} 5-\mathrm{R}-7$ were $>99.9 \%$ similar to each other and formed a well-defined and separate cluster supported by high bootstrap values ( $99 \%)$. Sequence similarity calculations indicated that the closest relative of these strains was T. japonica $(98 \%)$. Lower sequence similarities ( $\sim 97 \%)$ were found with all species of the genus Tetrasphaera with validly published names.

DNA-DNA hybridization was performed using microplate hybridization methods (Ezaki et al., 1989). Isolates 3-M5$\mathrm{R}-4^{\mathrm{T}}$ and 3-M5-R-7 were closely related to each other (71 and $84 \%$ DNA relatedness values with each other) suggesting that they are members of the same species, but exhibited relatively low levels of hybridization with

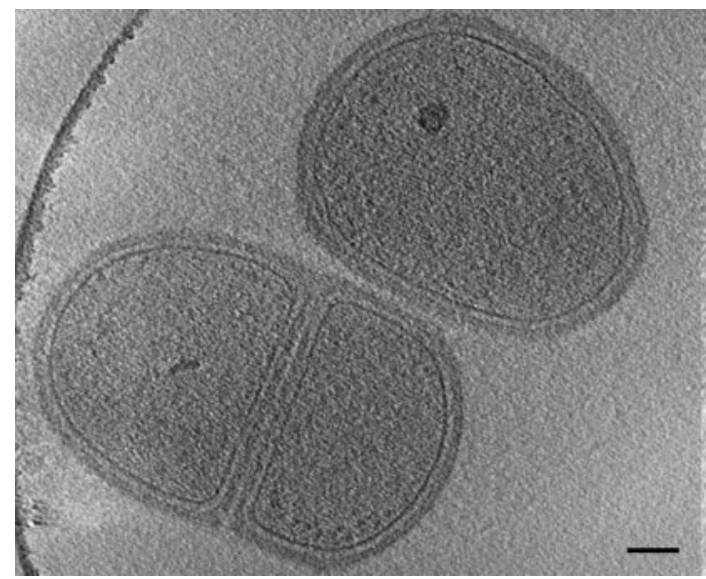

Fig. 1. Electron microscope image of cells of Tetrasphaera remsis sp. nov. $3 M 5-R-4^{T}$. The image is a $19 \mathrm{~nm}$-thick section of the tomogram. Bar, $100 \mathrm{~nm}$. Cells contain vesicles with electrondense material. Diploid cells and a single cell are shown, but the cells can also form tetrads (not shown). 
their nearest neighbour, T. japonica ACM $5116^{\mathrm{T}}$ (less than $16 \%)$. These findings strongly indicate that the two isolates represent a novel species of the genus Tetrasphaera.

Cellular fatty acid methyl esters were analysed with the Microbial ID system according to the manufacturer's instructions; results are given in Table 2. The fatty acid profiles of strains $3-\mathrm{M} 5-\mathrm{R}-4^{\mathrm{T}}$ and $3-\mathrm{M} 5-\mathrm{R}-7$ revealed a high percentage of branched-chain fatty acids (iso- $\mathrm{C}_{16: 0}$ ), as reported in the majority of other Tetrasphaera species (Hanada et al., 2002). The presence of both stearic and oleic acids distinguished 3-M5-R-4 ${ }^{\mathrm{T}}$ and 3-M5-R-7 from other Tetrasphaera species. The two strains contained larger amounts of octadecanoic acid $\left(\mathrm{C}_{18: 0}\right)$ and cis-9octadecenoic acid $\left(\mathrm{C}_{18: 1}\right)$ than the other Tetrasphaera species (approx. 12 and $22 \%$ greater, respectively). Although $\mathrm{C}_{18: 0}$ has been reported in Sanguibacter species (Fernandez-Garayzabal et al., 1995), $\mathrm{C}_{18: 1}$ was not found. In addition, $\mathrm{C}_{16: 0}$ was not found in strains $3-\mathrm{M} 5-\mathrm{R}-4^{\mathrm{T}}$ and 3-M5-R-7 in the elevated quantities (33-53\%) observed in Sanguibacter species.

Physiological and biochemical tests showed few phenotypic differences between the novel species described herein and other Tetrasphaera species. However, detection of elevated levels of certain fatty acids $\left(\mathrm{C}_{18: 0}\right.$ and $\left.\mathrm{C}_{18: 1}\right)$ as well as genotypic analyses allowed these gelatin-liquefying strains to be differentiated from the seven Tetrasphaera species. It is therefore proposed that strains $3-\mathrm{M} 5-\mathrm{R}-4^{\mathrm{T}}$ and 3-M5-R-7 represent a novel species in the genus Tetrasphaera, for which the name Tetrasphaera remsis sp. nov. is suggested.

\section{Description of Tetrasphaera remsis sp. nov.}

Tetrasphaera remsis (rem'sis. N.L. gen. n. remsis of/from REMS, acronym for Regenerative Enclosed Life Support Module Simulator).

Cells are Gram-positive, non-motile cocci $(0.5-1.0 \mu \mathrm{m}$ diameter), occurring in diploid, tetrad and cluster arrangements. Spore formation is not observed. Colonies are beige-coloured and convex with a glossy surface. Aerobic chemoheterotroph. Does not reduce nitrate to
Table 2. Cellular fatty acid compositions (\%) of the novel strains and type strains of Tetrasphaera species

Strains: 1, 3M5-R-4 $4^{\mathrm{T}} ; 2$, 3M5-R-7 (data from this study); 3, T. vanveenii DSM $17518^{\mathrm{T}} ; 4$, T. jenkinsii DSM $17519^{\mathrm{T}} ; 5$, T. veronensis DSM $17520^{\mathrm{T}}$ (data in columns 3-5 from McKenzie et al., 2006); 6, T. japonica DSM $13192^{\mathrm{T}}$ (data from Maszenan et al., 2000); 7, T. australiensis ACM $5117^{\mathrm{T}}$ (Hanada et al., 2002); 8, T. elongata DSM $14184^{\mathrm{T}}$ (Hanada et al., 2002); 9, T. duodecadis IAM $14868^{\mathrm{T}}$ (Ishikawa \& Yokota, 2006). - , Not detected or below $1 \%$. Values over $10 \%$ are in bold. Abbreviations: i, iso; ai, anteiso.

\begin{tabular}{|c|c|c|c|c|c|c|c|c|c|}
\hline Fatty acid & 1 & 2 & 3 & 4 & 5 & 6 & 7 & 8 & 9 \\
\hline $\mathrm{i}-\mathrm{C}_{14: 0}$ & 0.8 & 0.9 & 2.5 & 2.2 & 5.1 & - & 2.6 & 7.9 & 1.9 \\
\hline $\mathrm{C}_{14: 0}$ & 1.0 & 1.0 & 1.4 & 3.2 & 1.7 & - & - & - & - \\
\hline $\mathrm{i}-\mathrm{C}_{15: 0}$ & 9.0 & 9.4 & 18.7 & 17.2 & 8.8 & 6.4 & 12.1 & 19.9 & 15.8 \\
\hline ai- $C_{15: 0}$ & - & - & 2.4 & 2.8 & 1.3 & 3.0 & 7.6 & 30.6 & - \\
\hline$C_{15: 0}$ & - & - & 6.8 & 3.1 & 3.2 & 1.1 & 4.0 & - & 2.0 \\
\hline $\mathrm{C}_{15: 1}$ & - & - & 3.3 & 1.0 & 1.9 & - & - & - & - \\
\hline $\mathrm{i}-\mathrm{C}_{16: 0}$ & 13.7 & 14.6 & 30.3 & 21.0 & 49.9 & 25.8 & 27.1 & 4.2 & 17.8 \\
\hline$C_{16: 0}$ & 5.8 & 5.9 & 2.8 & 8.1 & 3.6 & - & 5.9 & 7.9 & 2.7 \\
\hline $\mathrm{i}-\mathrm{C}_{16: 1}$ & - & - & 7.8 & 2.3 & 10.1 & 3.2 & 9.7 & - & - \\
\hline$C_{16: 1}$ & 3.3 & 3.1 & 3.1 & - & 5.9 & 5.6 & 8.4 & - & - \\
\hline $\mathrm{i}-\mathrm{C}_{17: 0}$ & 6.1 & 6.2 & 1.1 & 4.4 & - & 2.2 & 2.0 & - & 3.9 \\
\hline ai- $C_{17: 0}$ & 1.8 & 1.8 & 2.5 & 5.8 & 6.0 & 20.5 & 14.1 & 1.5 & 21.8 \\
\hline$C_{17: 0}$ & 6.7 & 6.5 & 2.8 & 4.9 & 1.1 & 1.3 & - & 3.2 & 6.1 \\
\hline $\mathrm{i}-\mathrm{C}_{18: 0}$ & 2.4 & 2.3 & - & 1.9 & - & 5.3 & - & - & - \\
\hline $\mathrm{i}-\mathrm{C}_{17: 1}$ & 0.8 & 1.1 & 2.1 & 1.2 & - & 2.3 & - & - & - \\
\hline $\mathrm{C}_{17: 1}$ & 5.4 & 5.8 & 7.1 & - & - & - & - & 1.1 & - \\
\hline ai- $C_{17: 1}$ & - & - & 1.5 & 1.1 & 1.5 & 6.9 & 4.7 & - & - \\
\hline $\mathrm{i}-\mathrm{C}_{18: 1}$ & - & - & - & - & - & 1.3 & - & - & 5.1 \\
\hline $\mathrm{C}_{18: 0}$ & 12.9 & 12.2 & - & 1.6 & - & - & - & - & 11.8 \\
\hline $\mathrm{C}_{18: 1}$ & 23.4 & 22.4 & - & - & - & 2.2 & 3.7 & - & - \\
\hline
\end{tabular}

nitrite. Does not grow anaerobically or ferment glucose. Liquefies gelatin and hydrolyses aesculin. Produces catalase and $\beta$-galactosidase. Utilizes D-glucose, D-mannose, Dmannitol, maltose, $\mathrm{N}$-acetylglucosamine and malate. Does not assimilate the following compounds: L-arabinose, gluconate, capric acid, adipic acid, phenylacetic acid and citrate. Oxidase, urease, arginine dihydrolase, lysine and ornithine decarboxylases and indole are not produced.

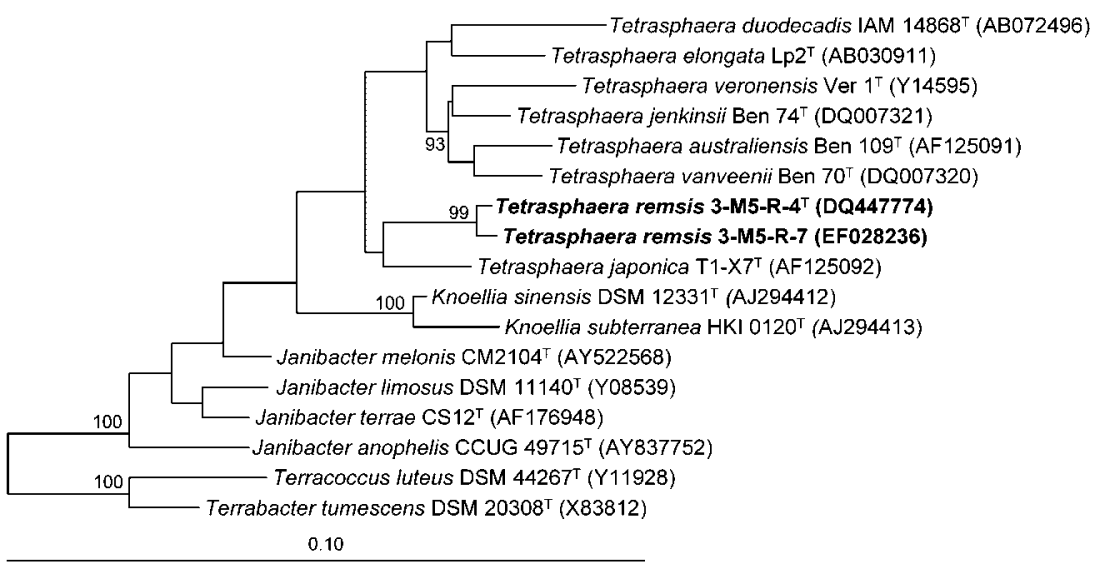

Fig. 2. Phylogenetic position of strains of Tetrasphaera remsis sp. nov. with members of Tetrasphaera and related genera. The tree was constructed on the basis of evolutionary distances calculated using the maximum-parsimony method and 1250 bases of the $16 \mathrm{~S}$ rRNA gene sequence were compared. Bar, 10 substitutions per 100 nucleotide positions. Significant bootstrap probabilities (>90\%, 1000 replications) are indicated at branch points. GenBank accession numbers are shown. 
Growth occurs at $15-45{ }^{\circ} \mathrm{C}$ and $\mathrm{pH}$ 6-9; optimal growth occurs at $25{ }^{\circ} \mathrm{C}$ and $\mathrm{pH}$ 7. The major cellular fatty acids are iso- $\mathrm{C}_{15: 0}$, iso- $\mathrm{C}_{16: 0}, \mathrm{C}_{18: 0}$ and $\mathrm{C}_{18: 1}$.

The type strain is strain $3-\mathrm{M} 5-\mathrm{R}-4^{\mathrm{T}}$ (=ATCC BAA-1496 ${ }^{\mathrm{T}}$ $=$ CIP $109413^{\mathrm{T}}$ ).

\section{Acknowledgements}

The research described in this publication was carried out at the Jet Propulsion Laboratory, California Institute of Technology, under a contract with the National Aeronautics and Space Administration. This research was funded by the Advanced Environmental Monitoring and Control Program. We are grateful to Darrell Jan for funding. We would like to thank Joerg Nellen for providing a number of the Tetrasphaera strains used in this study. We are thankful to all the members of the Biotechnology and Planetary Protection Group, JPL, especially Tara Stuecker, James Bruckner, David Newcombe and Wayne Schubert for technical assistance such as sampling and subsequent analysis.

\section{References}

Blackall, L. L., Seviour, E. M., Bradford, D., Rossetti, S., Tandoi, V. \& Seviour, R. J. (2000). 'Candidatus Nostocoida limicola', a filamentous bacterium from activated sludge. Int J Syst Evol Microbiol 50, 703-709.

Carter, L., Tabb, D., Tatara, J. D. \& Mason, R. K. (2005). Performance qualification test of the ISS Water Processor Assembly (WPA) expendables. In Proceedings of the 35th International Conference on Environmental Systems, 11-14 July 2005, Rome, Italy. SAE Technical Paper 2005-01-2837.

Ezaki, T., Hashimoto, Y. \& Yabuuchi, E. (1989). Fluorometric deoxyribonucleic acid-deoxyribonucleic acid hybridization in microdilution wells as an alternative to membrane filter hybridization in which radioisotopes are used to determine genetic relatedness among bacterial strains. Int J Syst Bacteriol 39, 224-229.

Fernandez-Garayzabal, J. F., Dominguez, L., Pascual, C., Jones, D. \& Collins, M. D. (1995). Phenotypic and phylogenetic characterization of some unknown coryneform bacteria isolated from bovine blood and milk: description of Sanguibacter gen. nov. Lett Appl Microbiol 20, 69-75.

Hanada, S., Liu, W. T., Shintani, T., Kamagata, Y. \& Nakamura, K. (2002). Tetrasphaera elongata sp. nov., a polyphosphate-accumulating bacterium isolated from activated sludge. Int J Syst Evol Microbiol 52, 883-887.
Ishikawa, T. \& Yokota, A. (2006). Reclassification of Arthrobacter duodecadis Lochhead 1958 as Tetrasphaera duodecadis comb. nov. and emended description of the genus Tetrasphaera. Int J Syst Evol Microbiol 56, 1369-1373.

Ludwig, W., Strunk, O., Westram, R., Richter, L., Meier, H., Yadhukumar, Buchner, A., Lai, T., Steppi, S. \& other authors (2004). ARB: a software environment for sequence data. Nucleic Acids Res 32, 1363-1371.

Mastronarde, D. N. (1997). Dual-axis tomography: an approach with alignment methods that preserve resolution. J Struct Biol 120, 343-352.

Maszenan, A. M., Seviour, R. J., Patel, B. K. C., Schumann, P., Burghardt, J., Tokiwa, Y. \& Stratton, H. M. (2000). Three isolates of novel polyphosphate-accumulating Gram-positive cocci, obtained from activated sludge, belong to a new genus, Tetrasphaera gen. nov., and description of two new species, Tetrasphaera japonica sp. nov. and Tetrasphaera australiensis sp. nov. Int J Syst Evol Microbiol 50, 593-603.

McKenzie, C. M., Seviour, E. M., Schumann, P., Maszenan, A. M., Liu, J. R., Webb, R. I., Monis, P., Saint, C. P., Steiner, U. \& Seviour, R. J. (2006). Isolates of 'Candidatus Nostocoida limicola' Blackall et al. 2000 should be described as three novel species of the genus Tetrasphaera, as Tetrasphaera jenkinsii sp. nov., Tetrasphaera vanveenii sp. nov. and Tetrasphaera veronensis sp. nov. Int J Syst Evol Microbiol 56, 2279-2290.

Moissl, C., Hosoya, N., Bruckner, J., Stuecker, T., Roman, M. \& Venkateswaran, K. (2007). Molecular microbial community structure of the Regenerative Enclosed Life Support Module Simulator (REMS) air system. Int J Astrobiol 6, 131-145.

Murray, R. G. E., Doetsch, R. N. \& Robinow, C. F. (1994). Determinative and cytological light microscopy. In Methods for General and Molecular Bacteriology, pp. 21-41. Edited by P. Gerhardt, R. G. E. Murray, W. A. Wood \& N. R. Krieg. Washington, DC: American Society for Microbiology.

Saha, P., Krishnamurthi, S., Mayilraj, S., Prasad, G. S., Bora, T. C. \& Chakrabarti, T. (2005). Aquimonas voraii gen. nov., sp. nov., a novel gammaproteobacterium isolated from a warm spring of Assam, India. Int J Syst Evol Microbiol 55, 1491-1495.

Staneck, J. L. \& Roberts, G. D. (1974). Simplified approach to identification of aerobic actinomycetes by thin-layer chromatography. Appl Microbiol 28, 226-231.

Zheng, Q. S., Braunfeld, M. B., Sedat, J. W. \& Agard, D. A. (2004). An improved strategy for automated electron microscopic tomography. J Struct Biol 147, 91-101. 